\title{
Peningkatan Kesadaran Diri Pada Makanan Bergizi Melalui Metode "Isi Piringku" Pada Anak Usia 4-5 Tahun Di TK PGRI Payungan Kecamatan Kaliwungu Kabupaten Semarang
}

\author{
Irna Anjarsari, Peni Listyaningsih, Ririn Linawati, Radeni Sukma Indra Dewi
}

Prodi Pendidikan Guru Pendidikan Anak Usia Dini, Fakultas Keguruan dan Ilmu Pendidikan, Universitas IVET, Indonesia

\section{Info Articles}

Sejarah Artikel:

Disubmit 7 Juli 2021

Direvisi 9 Juli 2021

Disetujui 31 Juli 2021

\section{Keywords:}

nutritional food; food

grouping; collaborative

action research; plastic

plate media; color;

\section{Abstrak}

Anak-anak di TK PGRI Payungan mengalami kesulitan untuk membedakan atau menggelompokkan jenis makanan pokok dan lauk pauk, kurangnya kesadaran anak untuk mengomsumsi sayur atau lauk pauk yang sehat saat membawa bekal, dan anak jarang menghabiskan sayur atau buah yang tersedia saat makan bersama. Metode "Isi Piringku" merupakan kegiatan yang dilakukan dengan bermain yang menggunakan media dari piring plastik yang aman untuk anak dan divisualkan secara menarik dengan warna. Tujuan penilitian ini adalah meningkatkan kesadaran diri pada makanan bergizi dengan menggunakan metode "isi piringku" pada anak usia 4-6 tahun. Jenis penelitian ini adalah Penelitian tindakan kolaboratif. Teknik pengumpulan data dilakukan dengan teknik wawancara dengan kepala sekolah, teman sejawat dan wali murid, observasi kesadaran diri anak pada makanan bergizi dan dokumentasi. Data Siklus I hanya mencapai $40 \%$ dari kriteria indikator keberhasilan 75\%. Data Siklus II telah mencapai keberhasilan $75 \%$ dari 20 anak. Penelitian tindakan kolaboratif ini mampu untuk meningkatkan kesadaran diri anak pada makanan sehat yang dilakukan dengan metode "isi piringku" dimana anak dengan tanpa dipaksa untuk mengkonsumsi dan mampu menyebutkan makanan sehat tersebut. 


\section{Abstract}

Children in PGRI Payungan Kindergarten have difficulty distinguishing or classifying types of staple foods and side dishes, lack of awareness of children to consume healthy vegetables or side dishes when carrying their lunches, and children rarely finish the vegetables or fruit available when eating together. The "Fill My Plate" method is an activity carried out by playing using media from plastic plates that are safe for children and are visualized in an attractive way with color. The purpose of this research is to increase self-awareness of nutritious food using the "fill my plate" method in children aged 4-6 years. This type of research is collaborative action research. Data collection techniques were carried out by interviewing the principal, peers and guardians of students, observing children's self-awareness on nutritious food and documentation. Cycle I data only reached $40 \%$ of the success indicator criteria of $75 \%$. Cycle II data has achieved 75\% success from 20 children. This collaborative action research is able to increase children's self-awareness on healthy food which is carried out with the "fill my plate" method where children are not forced to consume and are able to mention these healthy foods. 


\section{PENDAHULUAN}

Pendidikan anak usia dini diberikan pada awal kehidupan anak untuk dapat berkembang secara optimal. Secara umum standar tingkat pencapaian perkembangan menggambarkan pertumbuhan dan perkembangan yang diharapkan dicapai anak pada rentang usia tertentu. Perkembangan anak yang dicapai merupakan integrasi aspek pemahaman nilai-nilai agama dan moral, fisik, kognitif, bahasa, dan sosial emosional. Pertumbuhan anak yang mencakup pemantauan kondisi kesehatan dan gizi mengacu pda panduan kartu menuju sehat (KMS) dan deteksi tumbuh kembang anak. Anak adalah penerus generasi keluarga dan bangsa, sehingga sangat penting untuk mendapatkan pendidikan yang baik sehingga potensi-potensi dirinya dapat berkembang dengan pesat. lembagalembaga pendidikan dapat berperan dan bertanggung jawab dalam memberikan berbagai macam stimulasi dan bimbingan yang tepat sehingga akan tercipta generasi penerus yang tangguh dan unggul.

Usia keemasan anak merupakan periode terpenting untuk merangsang pertumbuhan otak, melalui perhatian kesehatan, penyedian gizi yang cukup dan pelayanan pendidikan. Zat gizi dari makanan merupakan sumber utama untuk memenuhi kebutuhan anak tumbuh kembang optimal sehingga dapat mencapai kesehatan. Salah satu faktor yang mempengaruhi pertumbuhan dan perkembangan anak adalah nutrisi. Menurut Fida dan Maya (2012), nutrisi merupakan salah satu komponen yang penting dalam penunjang keberlangsungan proses pertumbuhan dan perkembangan anak. Pada masa awal pertumbuhan anak sangat membutuhkan zat gizi seperti protein, kabrohidrat, lemak, mineral, vitamin, dan air. Zat gizi yang dibutuhkan oleh anak tidak boleh kurang, karena akan menghambat pertumbuhan dan perkembangan anak. Dan zat gizi yang berlebihan juga akan berdampak buruk bagi kesehatan anak, yang menyebabkan terjadinya penumpukan kadar lemak yang berlebihan pada sel atau jaringan bahkan pada pembuluh darah.

Gizi adalah zat-zat yang dibutuhkan oleh tubuh melalui makanan yang dikonsumsi sehari-hari, gizi tersebut berfungsi untuk menghasilkan energi, membangun dan memelihara jaringan. Gizi menjadi bagian yang sangat penting bagi pertumbuhan dan perkembangan karena itu gizi sangat diperlukan oleh anak untuk mengembangankan segala aspek dan memberikan stimulasi untuk perkembangan otak. Menurut Siswanto (2010) bahwa pertumbuhan yang berhubungan dengan tinggi dan berat badan sangat dipengaruhi oleh kondisi internal, misalnya gizi yang di peroleh dari makanan. Gizi yang baik dan seimbang akan berpengaruh terhadap perumbuhan dan perkembangan serta aspek-aspek perkembangan anak.

Anak yang mengkonsumsi makanan sehat tentunya akan terhindar dari masalah stunting dan berbagai macam penyakit. Menurut Siahay (2021), Pemerintah berharap masyarakat memiliki kesadaran untuk memperbaiki pola hidup untuk mencegah stunting. Salah satu upaya yang saat ini sedang digalakkan oleh pemerintah adalah edukasi tentang Gerakan "Isi Piringku". Edukasi gerakan "Isi Piringku" ini bertujuan untuk mengatur pola makan sesuai dengan komposisi makanan yang sudah dibagi sesuai dengan takaran yang baik untuk dikonsumsi oleh anak sesuai dengan umur. Sekilas konsep isi piringku ini mengadopsi konsep My Plate milik Amerika Serikat, yang membedakan hanya porsi dan susunan hidangan yang terdapat di dalamnya. Menurut Permenkes RI 
No. 41 Tahun 2014, Isi piringku mengambarkan tentang seberapa banyak makanan yang harus ada di dalam sebuah piring serta jenis makanan seperti apa yang sebaiknya anda pilih. Gambaran umum porsi makanan dalam isi piringku dalam sekali makan ialah: Makanan pokok sebanyak $2 / 3$ dari $1 / 2$ piring, Lauk pauk (sumber protein) sebanyak $1 / 3$ dari $1 / 2$ piring, Buah-buahan sebanyak $1 / 3$ dari $1 / 2$ piring, Sayur-sayuran sebanyak $2 / 3$ dari $1 \frac{1}{2}$ piring.

Kesadaran akan pentingnya makanan sehat, perlu di tanamkan sejak usia dini, dimana masa keemasaan ini merupakan pondasi awal anak belajar menjadi pribadi yang mandiri dan mampu bersosialisasi dengan lingkungannya. Winnicot dalam Wiyani (2013) mengungkapkan bahwa anak usia dini belajar untuk tumbuh dan berkembang secara cepat dan tak terduga. Anak usia dini memperoleh kebiasaannya melalui bermain, makanan kesukaannya, dan kapan waktunya untuk tidur. Semua kegiatan tersebut dipilih dan merupakan kebutuhan fisik mereka. Menurut Wiyani (2013) kemandirian anak usia dini dalam melakukan prosedur-prosedur keterampilan merupakan kemampuan untuk melakukan aktivitas sederhana seperti makan tanpa harus disuapi, mampu memilih bekall yang akan dibawanya saat kegiatan belajar.

Kenyataan yang terjadi di TK PGRI Payungan, 16 dari 20 anak usia 4-6 tahun kesulitan membedakan atau menggelompokkan jenis makanan pokok dan lauk pauk, kurangnya kesadaran anak untuk mengomsumsi sayur atau lauk pauk yang sehat saat membawa bekal, dan anak jarang menghabiskan sayur atau buah yang tersedia saat makan bersama.

Metode "Isi Piringku"merupakan kegiatan yang dilakukan dengan bermain yang menggunakan media dari piring plastik yang aman untuk anak dan di visualkan secara menarik dengan warna. Untuk memecahkan permasalahan tersebut, makan dilakukan penelitian tindakan kolaboratif melibatlkan beberapa pihak yang bertujuan untuk meningkatkan kesadaran diri pada makanan bergizi dengan menggunakan metode "isi piringku" pada anak usia 4-6 tahun di TK PGRI Payungan.

Rumusan masalah pada penelitian ini adalah: adakah perubahan sikap perilaku sadar akan makanan bergizi saat proses kegiatan belajar dengan metode "isi piringku". Tujuan penilitian ini adalah meningkatkan kesadaran diri pada makanan bergizi dengan menggunakan metode "isi piringku" pada anak usia 4-6 tahun.

\section{METODE}

Jenis penelitian ini adalah penelitian tindakan kelas (PTK) kolaboratif yang merupakan penelitian tindakan oleh guru yang dilakukan didalam kelas (karena masa pandemi dan pembelajaran dilaksanakan secara daring maka penelitian dilakukan di rumah peserta didik). Menurut Purnama dkk (2020) PTK kolaboratik adalah jenis PTK yang melibatkan dua orang guru atau lebih dalam merencanakan penelitian yang sama, melakukan tindakan yang sama, mendiskusikan hasil, dan melakukan refleksi bersama. Kolaborasi dapat dilakukan dengan ahli atau professional.

Subyek penelitian dalam skripsi ini adalah anak didik TK PGRI Payungan yang berjumlah 20 anak, terdiri dari 11 anak laki-laki dan 9 anak perempuan. Penelitian dilakukan selama 3 bulan yaitu bulan Desember 2020 - Februari 2021. 
Teknik pengumpulan data dilakukan dengan teknik wawancara kepala sekolah, teman sejawat dan wali murid, observasi kesadaran diri anak pada makanan bergizi dan dokumentasi. Dalam penelitian ini, peneliti menggunakan model Mc Taggart dengan dua siklus. Setiap siklus dilaksanakan sebanyak tiga kali pertemuan yang setiap pertemuan meliputi tahapan, perencanaan, pelaksanaan, tindakan, observasi dan refleksi. Instrument penelitian ini menggunakan instrument rencana pelaksanaan pembelajaran harian dan lembar observasi kesadaran diri pada makanan bergizi dengan metode "isi piringku". Untuk mengetahui prosentase keberhasilan dengan membandingkan ketuntasan anak belajar sebelum adanya pembelajaran tentang makan-makanan bergizi dan sesudah adanya pembelajaran tentang makan-makanan bergizi. Untuk menghitung analisis anak didik pada waktu proses pembelajaran menggunakan rumus sebagai berikut:

$$
P=\frac{F}{N} \times 100 \%
$$

$$
\begin{aligned}
\text { Dimana }: & P=\text { Prosentase } \\
& F=\text { Frekuensi } \\
& N=\text { Jumlah Anak }
\end{aligned}
$$

Kriteria keberhasilan untuk setiap siklus adalah jika seluruh subjek penelitian a) anak dapat mengelompokkan makanan pokok, sayuran, lauk b) anak dapat menyebutkan makanan kesukaan, c) anak dapat memperagakan makan yang tertib dan sopan, d) memperoleh skor pada akhir tindakan (Berkembang Sesuai Harapan) $\geq 75 \%$.

\section{HASIL DAN PEMBAHASAN}

Kegiatan prasiklus, peneliti memberikan media belajar berupa media gambar tentang makanmakanan bergizi pada anak-anak kelompok A TK PGRI Payungan sebagai sarana awal untuk diambil datanya dalam pemahaman tentang makan-makanan bergizi. Data hasil prasiklus menunjukkan bahwa : anak yang belum berkembang (BB) sejumlah 10 anak dengan prosentase $50 \%$, mulai berkembang (MB) sejumlah 6 anak dengan prosentase sebesar 30\%, anak yang berkembang sesuai harapan (BSH) sebanyak 4 anak didik dengan prosentase $20 \%$, dan kategori berkembang sangat baik (BSB) sejumlah 0 dengan prosentase $0 \%$

Kegiatan siklus I, peneliti memberikan kegiatan belajar mengajar dengan metode "isi piringku dari media piring plastik dengan makanan pokok, lauk pauk, sayur, dan buah-buahan. Data hasil penelitian di siklus I, dapat dikategorikan ke dalam beberapa perkembangan sesuai dengan indikator penelitian. Data tersebut menunjukkan bahwa anak Belum Berkembang (BB) sejumlah 6 anak dengan prosentase 30\%, mulai Berkembang (MB) berjumlah 6 anak dengan prosentase $30 \%$, Berkembang Sesuai Harapan (BSH) berjumlah 6 anak dengan prosentase 30\%, berkembang Sangat Baik (BSB) 2 dengan prosentase $10 \%$.

Refleksi dari kegiatan di siklus I, dengan kegiatan bermain dan belajar mengunakan metode "isi piringku" dengan media piring plastik dengan makanan pokok, lauk pauk, sayur, dan buah- 
buahan, hanya mencapai $40 \%$ dari kriteria indikator keberhasilan 75\%. Kegiatan di siklus I, anak masih beradaptasi dengan makanan baru yang di berikan, terlihat beberapa anak tidak mau menyentuh atau memakan makanan tersebut. Tindak lanjut dari siklus 1 adalah peneliti menggunakan metode "isi piringku" dengan permainan yang lebih menarik minat anak.

Kegiatan siklus II, peniliti memberikan kegiatan belajar mengajar dengan metode "isi piringku" dari media piring plastik dengan makanan pokok, lauk pauk, sayur, dan buah2 buahan . Data hasil penilitian di siklus II, dapat dikategorikan kedalam beberapa perkembangan sesuai dengan indikator penelitian. Data tersebut menunjukkan bahwa anak Belum Berkembang (BB) sejumlah 0 anak dengan prosentase $0 \%$, mulai Berkembang (MB) berjumlah 5 anak dengan prosentase $25 \%$, Berkembang Sesuai Harapan (BSH) berjumlah 10 anak dengan prosentase $50 \%$, berkembang Sangat Baik (BSB) 5 dengan prosentase 25\%.

Refleksi dari kegiatan di siklus II, dengan kegiatan bermain kecepatan mengelompokkan makanan pokok, lauk pauk, sayuran dan buah-buahan dalam piring, telah mencapai keberhasilan $75 \%$ dari 20 anak. Secara garis besar bahwa pada hasil kegiatan siklus II mengalami peningkatan dari siklus sebelumnya. Hasil penelitian pada siklus II sudah menunjukkan hasil sesuai dengan indikator keberhasilan penelitian, oleh karena itu tidak diperlukan lagi kegiatan siklus selanjutnya.

Tabel 1. Rekap hasil observasi anak

\begin{tabular}{|c|c|c|c|c|c|c|c|c|}
\hline \multirow[b]{2}{*}{ No } & \multirow[b]{2}{*}{ Kategori } & \multirow[b]{2}{*}{ Skor } & \multicolumn{2}{|c|}{ Pra Siklus } & \multicolumn{2}{|c|}{ Siklus I } & \multicolumn{2}{|c|}{ Siklus II } \\
\hline & & & $\begin{array}{c}\text { Jumlah } \\
\text { Anak }\end{array}$ & $\%$ & $\begin{array}{c}\text { Jumlah } \\
\text { Anak }\end{array}$ & $\%$ & $\begin{array}{c}\text { Jumlah } \\
\text { Anak }\end{array}$ & $\%$ \\
\hline 1 & BSB & 4 & 0 & 0 & 2 & 10 & 5 & 25 \\
\hline 2 & $\mathrm{BSH}$ & 3 & 4 & 20 & 6 & 30 & 10 & 50 \\
\hline 3 & $\mathrm{MB}$ & 2 & 6 & 30 & 6 & 30 & 5 & 25 \\
\hline 4 & $\mathrm{BB}$ & 1 & 10 & 50 & 6 & 30 & 0 & 0 \\
\hline & Jumlah & & 20 & 100 & 20 & 100 & 20 & 100 \\
\hline
\end{tabular}

Pembiasaan makan - makanan sehat di mulai dengan pengenalan makanan dan minuman yang sering dijumpai dan mudah untuk mendapatkannya, seperti : ubi, wortel, brokoli, bayam, jeruk, puding, macam-macam jus buah, sari kacang hijau, susu kedelai. Untuk melatih kemandirian, anak dipersilahkan untuk cuci tangan pakai sabun dengan air mengalir tanpa bantuan orang lain. Anak belajar makan sendiri tanpa disuapi. Hal ini dimaksudkan untuk melatih anak untuk mandiri dan bertanggung jawab atas apa yang telah dilakukan. Untuk membantu anak terbiasa dan menjadi kebiasaan sehari- hari, peneliti meminta dukungan orantua untuk belajar dari rumah dengan metode "isi piringku" dengan mengedukasi dan memberikan menu-menu makanan yang menarik minat anak.

\section{SIMPULAN}


Meningkatkan kesadaran diri anak pada makanan sehat dapat dilakukan dengan metode "isi piringku" yang dimana anak dengan tanpa dipaksa untuk mengkonsumsi dan mampu menyebutkan makanan sehat tersebut. Hal ini dibuktikan dengan hasil penelitian di siklus II meningkat dari $40 \%$ menjadi 75\% sejumlah 15 anak dengan kategori Berkembang Sesuai Harapan (BSH) dan Berkembang Sangat Baik (BSB).

\section{DAFTAR PUSTAKA}

Ali Khomsan. 2010. Pangan dan Gizi untuk Kesehatan. Jakarta: PT Raja Grafindo Persada

Departemen Gizi \& Kesehatan Masyarakat. 2011. Gizi dan Kesehatan Masyarakat. Jakarta: PT Raja Grafindo Persada

Fida dan Maya, 2012. Pengantar ilmu Kesehatan Anak. Jogyakarta : D-Medika

Moleong. Lexi J. 2012. Metode Penelitian Kualitatif, Bandung: PT Remaja Rosdakarya

Nurul Chomaria. 2015. Panduan Terlengkap Tumbuh Kembang anak Usia 0-5 Tahun. Surakarta: Cinta Menebar Cinta Menuai Hikmah.

Peraturan Menteri Kesehatan Republik Indonesia Nomor 41 tahun 2014. Jakarta: Menteri Kesehatan.

Peraturan Menteri Pendidikan Nasional Republik Indonesia Nomor 137 Tahun 2014 Tentang Standar Pendidikan Anak Usia Dini. Jakarta : Departemen Pendidikan Nasional

Purnama, Sigit dkk. 2020. Penelitian Tindakan Kelas untuk Pendidikan Anak Usia Dini. Bandung: PT Remaja Rosdakarya.

Proverawati Atika dan Kusuma Erna. 2011. Ilmu Gizi Keperawatan dan Gizi Kesehatan. Yogyakarta: NUH Medika

Siahaya, Alisye dkk. 2021. Edukasi"isi pringku" terhadap pengetahuan dan perilaku pada ibu balita stunting di Maluku. Universitas Muhammadiyah Jakarta: Jurnal penelitian kesehatan Suara Forikes. Volume 12. Hal. 199-202

Siswanto, Hadi. 2010. Pendidikan Kesehatan Anak Usia Dini.Yogyakarta:Pustaka Rihama

Warsito, Heri, dkk. 2015. Ilmu Bahan Makanan Dasar. Yogyakarta: Nuha Medika

Wiyani, Novan A. 2013. Bina karakter Anak Usia dini. Yogyakarta: Ar-Ruzz Media.

Wiwi Sartika, dan Mitayani. 2013. Buku Saku ilmu Gizi. Jakarta:CV. Trans Info Media.

Wulandari, Dewi dan Meira Erawati.2016. Buku Ajara Keperawatan Anak. Pustaka Pelajar 